IZA DP No. 5658

The Impact of Worker Effort on Public Sentiment Towards Temporary Migrants

Gil S. Epstein

Alessandra Venturini

April 2011 


\title{
The Impact of Worker Effort on Public Sentiment Towards Temporary Migrants
}

\author{
Gil S. Epstein \\ Bar-Ilan University, \\ CReAM and IZA
}

\author{
Alessandra Venturini \\ University of Turin, CARIM \\ and IZA
}

Discussion Paper No. 5658

April 2011

IZA

P.O. Box 7240

53072 Bonn

Germany

Phone: +49-228-3894-0

Fax: +49-228-3894-180

E-mail: iza@iza.org

\begin{abstract}
Any opinions expressed here are those of the author(s) and not those of IZA. Research published in this series may include views on policy, but the institute itself takes no institutional policy positions.

The Institute for the Study of Labor (IZA) in Bonn is a local and virtual international research center and a place of communication between science, politics and business. IZA is an independent nonprofit organization supported by Deutsche Post Foundation. The center is associated with the University of Bonn and offers a stimulating research environment through its international network, workshops and conferences, data service, project support, research visits and doctoral program. IZA engages in (i) original and internationally competitive research in all fields of labor economics, (ii) development of policy concepts, and (iii) dissemination of research results and concepts to the interested public.
\end{abstract}

IZA Discussion Papers often represent preliminary work and are circulated to encourage discussion. Citation of such a paper should account for its provisional character. A revised version may be available directly from the author. 
IZA Discussion Paper No. 5658

April 2011

\section{ABSTRACT}

\section{The Impact of Worker Effort on Public Sentiment Towards Temporary Migrants*}

Temporary and circular migration programs have been devised by many destination countries and supported by the European Commission as a policy to reduce welfare and social costs of immigration in destination countries. In this paper we present an additional reason for proposing temporary migration policies based on the characteristics of the foreign labor-effort supply. The level of effort exerted by migrants, which decreases over their duration in the host country, positively affects production, real wages and capital owners' profits. We show that the acceptance of job offers by migrants result in the displacement in employment of national workers. However it increases the workers' exertion, decreases prices and thus can counter anti-immigrant voter sentiment. Therefore, the favorable sentiment of the capital owners and the local population towards migrants may rise when temporary migration policies are adopted.

JEL Classification: Jo, HO

Keywords: migration, exertion of effort, contracted temporary migration

Corresponding author:

Gil S. Epstein

Department of Economics

Bar-llan University

Ramat Gan

Israel

E-mail: Gil.Epstein@Biu.ac.il

\footnotetext{
* The first author is grateful for the support of the Adar Foundation.
} 


\section{Introduction}

Migration is a never-ending problem in modern society. The debate on the best immigration policy has been ongoing since the colonial period and grew increasingly intense in the last century when the destination countries began to impose controls on immigration.

The core issue in this debate is finding the appropriate policy with which to favor a positive effect of immigration, at least in the destination countries. Should policies be more open or more restrictive, should they be selective or otherwise?

There are three main arguments backing this choice: The first is the effect of foreigners on the labor market in the destination country. Are migrants competing with natives in the labor market or are they complementary? Should policies be more restrictive or should they be more open? Should the migrants be skilled or unskilled? The empirical literature from Europe, the USA, Canada, and Australia finds little evidence of wage competition and employment competition. The debate continues, but it is centered on the econometric techniques which enable better measurement of the foreign effect and better control for the endogeneity of migration location. ${ }^{1}$ The second line of reasoning starts after the conclusion of the first. Even if migrants are not strong competitors in the labor market, they use the welfare system, in some countries more than the natives do. Some authors have even suggested the existence of 'welfare shopping' whereby migrants locate and where the welfare system is more generous (Borias 1999), but significant evidence of this does not exist, with the exception of the findings by De Giorgi and Pellizzari (2006). In countries where welfare systems are more generous, especially in Europe, there exists evidence that supports a larger use of the foreign population on welfare, i.e. in Germany, the United Kingdom and Sweden. ${ }^{2}$ This welfare declines if the migrants' characteristics are taken into account (Barrett and McCarthy, 2008, Pellizzari, 2011) ${ }^{3}$. This result is supported

\footnotetext{
${ }^{1}$ The debate was first dominated by the Borjas (1994)-Filer (1992)-Card (2005) puzzle namely that in a cross-spatial analysis the complementary of immigrants may be induced by the internal mobility of natives from an increasing migration and declining wage area to a non-increasing immigration area. The latter area is contaminated by the former labor market affect and conceals the negative impact of immigrants in the first area. Then, to overcome this weakness, the debate shifted to the skill-cell approach in a production function model with mixed results by Borjas (2003)-Ottaviano Peri (2006).

${ }^{2}$ See e.g. Castronova et al. (2001) and Riphan (2004) for Germany, Barrett and McCarthy (2008) for the United Kingdom, and Hansen and Lofstrom (2003) for Sweden.

${ }^{3}$ On general problems of the welfare state, see Hans-Werner Sinn (1995).
} 
by the many empirical studies conducted on wage and employment assimilation. ${ }^{4}$ The third line of argument stresses the difficult and limited social assimilation of foreigners: even the second generation seems unable to integrate into the social life of the destination country. Both the "melting pot" (Glazer and Moynihan 1970) and the "bumpy line" theories of assimilation (Gans 1979, 1996) questioned the previous positive view of the immigrant integration process, and the "segmented assimilation paradigm", developed by Portes and Zou (1993), put an end to them: it interpreted social upgrading either as specific and occasional individual action or as an organized group activity which is not always successful. These three arguments have given new support for a temporary migration policy which may solve the difficulties of integrating foreigners economically and socially, and possibly reduce to some extent their welfare costs and competition in the labor market.

New emphasis has been given within the European Commission ${ }^{5}$ to the proposal of circular migration policies. These seemingly re-propose the temporary migration policies adopted in North Europe until the oil price increase of 1973 and the beginning of the recession, but in fact they represent a new vision of the international mobility pattern. Temporary migration will not only solve competition, economic, social integration and welfare costs in the destination countries it will also favor the economic growth of sending countries by reducing brain drain and contrasting the negative effects of remittances, which frequently create a subsidized economy and reduce the labor force participation rate and the future growth path. ${ }^{6}$

In this paper we suggest another reason for pursuing temporary migration. This is based on an efficient use of human resources by the employer and a maximization of the utility of consumers. Whereas Dustman and Weiss (2007) analyze the incentives for migrants to adopt short-stay migration plans, we analyze their labor productivity and the implications of the employer's maximizing decisions and for the consumers consumption levels, which will both be in favor of short stopover.

On the political economic side, studies on immigration policy investigate voters' attitudes to immigrants (see for example Mazza and van Winden 1996,

\footnotetext{
${ }^{4}$ See e.g. Dustman and Fabbri (2005) for the United Kingdom and Venturini and Villosio (2008) for Italy.

5 European Commission, "On Circular Migration and Mobility Partnerships between the European Union and Third Countries", COM (2007) final, Brussels, 16 May 2007.
} 
Benhabib 1996, Hillman and Weiss 1999) ${ }^{7}$. Such studies require an underlying basis which explains why a voter may support or object to immigration. One basis, which identifies personal gains and losses from immigration, is the standard fullemployment model of international trade and factor movements (see Kai-yiu Wong, 1995). Alternatively, all members of a local population may benefit when immigration reduces the domestic per capita tax burden for the financing of collective goods. Or, more generally, there may be benefits for the local population when immigration expands the domestic tax base, and, for example, allows the public financing of intergenerational transfers that might otherwise be unsustainable because of demographic imbalance in the local population (see Lee and Miller 1998, Bonin et al. 2000, Storesletten 2000, Hillman 2002). Epstein and Hillman (2003) consider employed workers who pay taxes, which finance income transfers to the unemployed, and find that immigrants initially displace national workers from the unemployment pool. The real wage declines because of immigration, but the probability of a local worker being employed increases. Although employed workers finance income transfers to the unemployed, immigration, within designated bounds, increases the expected utility of local workers. Since employers benefit from immigration, there are immigration policies which are mutually beneficial to all voters, whether they are local employees or employers, although employers will want more immigrants than workers.

In this paper we take a different view by looking at the effort exerted by migrants during their stay or work in the host country. We suggest a possible interpretation of why migrants, at least in the initial period in the host country, exert more effort than the local population. When immigrants arrive in the host country they may accept jobs which entail long hours of work. For example, female immigrants employed in family services frequently work around the clock. This implies that migrants' working hours are uncertain and that they enjoy little freedom and free time. The longer they stay in the destination country, the more they are reluctant to accept such jobs. They prefer normal hours with leisure time. A similar pattern is apparent in other types of service jobs. In addition, migrants in agricultural accept long working hours, and may be willing to perform the heaviest tasks in the

\footnotetext{
${ }^{6}$ See e.g. Newland and Agunias (2007).
} 
industrial sector. Not only are they willing to work overtime, but they are also very flexible and willing to accept last-minute changes. The results of our paper have a similar flavor to those presented by Galor and Stark (1991). Their paper builds on the idea that migrants consider the possibility of eventually returning to their (low-wage) country of origin and thus may have an incentive to work harder in the (high-wage) country of destination. Our paper does not consider this incentive. If we would add this incentive our results would even be further enhanced.

We consider an efficiency wage model to analyze the choice of local workers and migrants regarding the exertion of effort in the workplace. The level of effort affects the consumption patterns of both groups. When determining their level of consumption, individuals take into account the price of consumption. Upon arrival, immigrants evaluate the weighted average between the local price level and the price level in their home country ${ }^{8}$. With time, the weight of the price level in the home country decreases and it converges to the local price level. Therefore, the consumption patterns and the effort exerted merge with those of the local population.

The application of high effort and low consumption patterns has two different effects on the local population. Higher effort decreases the employment of the local population; however, a decrease in patterns of consumption by migrants increases the benefits for the local population.

Over time, both consumption patterns and the exertion of effort converge to those of the local population. Therefore, the sentiment of capital owners and the local population towards migrants may change when temporary migration policies are adopted. Under such policies, the temporary migrants will enter the country for a short period of time, exert a high level of effort in the workplace, and at the same time decrease the cost of consumption for the local population. These temporary migrants would leave at the end of the period and be replaced by new temporary migrants. ${ }^{9}$

\footnotetext{
${ }^{7}$ Epstein and Nitzan (2006) consider the role of interest groups in the determination of migration quotas.

${ }^{8}$ We are assuming that migrants come from countries with lower price levels. We will elaborate on this later in the paper. The value applied to the price level in the country of origin and in the host economy may be endogenous to the migration strategy and expected consumption patterns (temporary, permanent, permanent with remittances, etc). We will discuss this later on.

${ }^{9}$ On other benefits and costs of temporary migration and on optimally creating such a policy see Epstein, Hillman and Weiss (1999) and Boeri, Hanson and McCormick (2002). For a more general analysis of permit and temporary contracts see Venturini 2004 p.208-219.
} 
In section 2 we present some evidence on the variables at the heart of the model. The model is described in section 3 . The consumption pattern of immigrants is specified in section 4 . In section 5 we determine the equilibrium wage and the level of effort exerted in the case of homogeneous or heterogeneous human capital with or without inelastic supply of immigrants. Section 6 analyzes the implications of the efforts supplied by immigrants on the local labor and products. The paper concludes with some policy implications.

\section{Puzzling Empirical evidence.}

Our paper is motivated by some stylized facts. More specifically, research indicates two contradictory behaviors: when arriving in the host country migrants have low consumption levels and large saving. With time consumption increases, remittances decrease and the savings decrease. On the other hand, the effort invested by the migrant is higher initially and declines as the migrants become more integrated into the destination economy. Our model tries to understand this contradictory by considering the migrants' attitudes towards prices in both the home and host countries.

2.1 The first one is that in the initial phase of migration foreigners have a very limited consumption in the destination country, very large saving and large amount of remittances which they send back to the origin country. As migration goes on however consumption in the destination country increases, remittances decrease and the savings become more similar to the natives.

There is a large amount of empirical evidence which shows that the amount of remittances declines as the migrant becomes more integrated into the country of destination and decreases with family reunification (Funkhouser, 1995, Poirine, 1997, Galor and Stark ,1990, Carling, 2008). The reduction of the remittances, and the increase in the consumption in the destination countries, is frequently related to the reunification of the family but also to the more general assimilation process, where the assimilation in the consumption pattern prevailing in the destination country plays an important role.

De Voretz and Vadean (2005) point out that in Canada the migrants' remittances decline as the duration of residence in the host country increases. There 
are, however, differences among communities and the migration policies play an important role because if family reunification is allowed and favored from the commencement of the migration pattern, the amount of remittances sent back is reduced and their decline as well. The same is found in the Eastern European countries by Mansour and Quillin (2006) ${ }^{10}$ and in Europe by Holst, Schäfer, Schrooten (2010) for women migrants. The evidence, regarding the decline in remittances, is very well recorded.

Less evidence exists regarding consumption and saving behavior of the migrants in the destination country. The evidence stresses an increasing pattern of consumption and a declining one for savings. Kumku (1989) found in Germany a high saving rate for Turkish immigrants in their first few years and Kirdar (2009) found that the saving rate decreases with age in Germany. More specifically Bauer and Sininng (2005), using GSOEP, show that in 2001 in Germany the saving rate of temporary migrants was larger than the saving rate of permanent migrants $(0.072$ versus 0.050 ) and the savings plus the remittances rate is higher for the temporary migrants than for the permanent ones (0.10 versus 0.066). In Sinning (2007) using the same data, it was established that temporary migrants save on average $16.7 \%$ more and send $20.6 \%$ more other transfers to their home country than permanent migrants. Similarly Piracha and Zhu (2007) find that among the migrants there are larger savings and remittances relative to the locals and this is interpreted as an insurance against an uncertain future. These savings decline as the integration in the destination country become more formalized.

For Italy, Speciale and Barigozzi (2009) find that the consumption of immigrants with higher permanence in the host country dominates the one with lower permanence. Migrants are not different from other consumers and are affected by the reference group and by emulating behavior (Maurer and Meier 2008).

2.2 The second empirical evidence is that the effort invested in the work is higher initially and declines as the migrants become more integrated into the destination economy.

\footnotetext{
${ }^{10}$ See for instance in the Mediterranean case Venturini (2004)
} 
The idea, that the initial effort of the migrant is bigger, belongs to the general perception of the foreign worker behavior (Schaeffer, 1995). Unfortunately, the information on the individual productivities is very rare. A proxy for this would be the amount of hours spent at the workplace. There does exist evidence regarding the number of hours worked. Kahanec and Shields (2010), using the GSOEP observe a reduction in hours worked as migrant tenure increases. Temporary migrants work on average 15 hours per week more than permanent ones. This behavior is reported for the USA labor market where Lozano (2010) finds that the probability of a migrant working long hours decreases significantly after five years being in the USA.

Cortes (2004) finds that in the USA refugees, with more permanent migration prospects, work $14 \%$ less than the more temporary economic migrants. A preliminary research by Reyneri (2011) on the Italian market indicates similar results. Also, in Italy total hours worked by migrants decrease after five years by at least $10 \%$, and the reduction is even larger for some groups: Moroccans reduce their contribution to production by $29 \%$ after five years, Bulgarian and Romanians by $25 \%$ and South Americans by $20 \%{ }^{11}$.

These two behaviors seem contradictory because when migrants increase consumption in the destination country, where prices are higher, we would expect an increase in working hours to gain extra money, and a relaxation of their budget constraints, while instead we observe a reduction in effort and hours worked on the job which seem irrational.

With the model below, we provide an interpretation of this puzzling behavior of the migrants which is very rational if regarded in term of real wage and the consumption basket that the migrant can afford.

\section{The model}

Consider a population which consists of owners of capital and workers. Workers consist of $N_{L}$ nationals and $N_{F}$ immigrants. All workers are risk neutral and averse to

\footnotetext{
${ }^{11}$ Emilio Reyneri, 2011, Preliminary results on the hours worked by migrants, mimeo.
} 
effort and have the same level of productivity ${ }^{12}$. The utility of the workers, $U($.$) , is a$ function of consumption, $C: U(C)$. As commonly assumed in such cases we assume that $U(C)=C$. Consumption is time consuming. To simplify, we assume that, on average, each unit of consumption needs one unit of time. Each worker has a total of $T$ units of time to consume. However, if a worker exerts effort at the workplace he has less time to consume (one could give this many explanations, for example, the more effort exerted at the workplace gives the worker less strength to consume expend at the end of the day, or the more time/effort spent at the workplace, leaves less time for consumption). Denote the effort exerted at the workplace by $e$ and the price of an average unit of consumption equals $P$. Therefore, the constraint facing the worker that emerges is: $P(T-e) \leq w_{N}$, where $w_{N}$ is the nominal wage of the worker. As the worker's objective is to maximize his utility (consumption) he/she will always set the total cost of consumption to equal the wage: $P(T-e)=w_{N}$. If the worker exerts minimum amount of effort at the workplace $\left(e=e_{L}\right)$ then his/her utility will equal $U\left(C, e=e_{L}\right)=\frac{w_{N}}{P}-e_{L}$, however if the worker does exert effort at a higher level $\left(e=e_{H}\right)$ the workers utility will equal $U\left(C, e=e_{H}\right)=\frac{w_{N}}{P}-e_{H}$. Namely, exerting effort decreases the consumption level. As the effort at the workplace increases the worker will be able to consume fewer products as a result of the time restriction. We therefore obtain, as assumed by Shapiro and Stiglitz (1984), Epstein and Hillman (2003) and others, that the utility is separable and linear in private consumption which is provided through expenditure of a real wage $w\left(w=w_{N} / P\right.$ where $w_{N}$ is the nominal wage and $P$ is the price level) and in the level of effort $e$,

$$
U(w, e)=w-e .
$$

To simplify we assume that effort is dichotomous, it either equals $e_{L}$ or $e_{H}>0{ }^{13}$. We always exert effort, whether employed or unemployed. Thus under this assumption $e$

\footnotetext{
${ }^{12}$ For the sake of our analysis, assuming that the level of productivity of the migrants is lower would only enhance our results.

${ }^{13}$ One could also imagine that migrants, when they arrive, do not consume leisure - they do not go to the cinema or have family meetings - thus their upper boundary of the effort devoted to work is higher.
} 
$=e_{L}$ is the minimum level of effort exerted by the worker. An unemployed worker receives benefits of $w_{o}$ from the state and exerts the minimal level of effort ( $\left.e=e_{L}\right)$. Welfare payments are the same for nationals and immigrants (immigrants are legal).

A worker has a probability $p$ of becoming unemployed for exogenous reasons which do not depend on the employer. All workers maximize present discounted utility, with a rate of time preference $r>0$. The model is set in continuous time. The only choice that a worker makes is selection of effort $e \in\left(e_{L}, e_{H}\right)$. A worker, who does not shirk, performs at a customary level of effort for the job, $e_{H}$, receives the wage $w$, and retains his or her job until he or she exogenously becomes unemployed. Employers imperfectly monitor effort. Workers, who shirk $\left(e=e_{L}\right)$, are detected and fired with probability per unit of time $q . \quad V_{e}(s, j)$ and $V_{e}(n, j)$ are expected lifetime utilities of an employed worker of type $j$ (immigrant or local) when shirking $(s)$ and when not $(n) . \quad V_{u}$ is the expected lifetime utility of an unemployed person ${ }^{14}$. For a shirker,

$$
r V_{e}(s, j)=w-e_{L}-(p+q)\left(V_{e}(s, j)-V_{u}\right)
$$

And for a non-shirker,

$$
r V_{e}(n, j)=w-e_{H}-p\left(V_{e}(n, j)-V_{u}\right)
$$

From (2) and (3):

$$
V_{e}(s, j)=\frac{\left(w-e_{L}\right)+(p+q) V_{u}(j)}{r+p+q}
$$

and

$$
V_{e}(n, j)=\frac{\left(w-e_{\mathrm{H}}\right)+p V_{u}(j)}{r+p} .
$$

No shirking takes place if and only if $V_{e}(s, j) \leq V_{e}(n, j)$ i.e.,

$$
w-e_{L} \geq r V_{u}(j)+\frac{(r+p+q)}{q} \Delta e_{H}
$$

Such that $\Delta e_{H}=e_{H}-e_{L}$. 
Production functions are given by $\tilde{f}\left(\bar{K}, L_{L} z_{L}+L_{H} z_{H}\right) \cdot \bar{K}$ is the available capital and $L_{L} z_{L}+L_{H} z_{H}$ is the amount of labor normalized by the effort exerted and the human capital level of the workers. $z_{i}=f\left(h_{N} e_{i} \frac{L_{N}}{L_{N}+L_{F}}+h_{F} e_{i} \frac{L_{F}}{L_{N}+L_{F}}\right) i=L, H . L_{\mathrm{L}}$ workers exert the minimum amount of effort $e_{L}$ and $L_{\mathrm{H}}$ workers exert the effort at the level of $e_{H}$. The incomes of owners of capital (or employers) increase when the number of workers who are employed increase. ${ }^{15}$ Demand for workers is given by the value of the marginal product, and is a decreasing function of the wage $w$. Equilibrium is defined as an outcome when owners of capital, taking as given wages and employment levels at the other firms, find it optimal to offer the going wage rather than a different wage, that is, there is a Nash equilibrium in wages paid by employers.

It is assumed that all workers receive the same wages. i.e. we are considering a pooling equilibrium where all workers, local and migrants receive the same wages. Thus the sole variable determining employers' decisions is the disciplining of employed workers through $V_{u}$, the expected utility of an unemployed worker.

Since all unemployed workers receive the same welfare benefits $w_{o}, V_{u}$ is common to all employees. An unemployed person's utility is thus independent of the identity of his or her previous employer. Hence

$$
r V_{u}(j)=w_{0}-e_{L}+k_{j}\left(V_{e}(j)-V_{u}(j)\right)
$$

where $k_{j}$ is the rate at which workers who are unemployed find jobs and $V_{e}(j)$ is the expected utility of an employed worker of type $j$, which in equilibrium equals $V_{e}(n, j)$. Substituting (8) into (4) and (5), we obtain

$$
r V_{e}(j)=\frac{\left(w-e_{H}\right)\left(k_{j}+r\right)+\left(w_{o}-e_{L}\right) p_{j}}{k_{j}+p_{j}+r} \text { and } r V_{u}(j)=\frac{\left(w-e_{H}\right) k_{j}+\left(w_{o}-e_{L}\right)\left(r+p_{j}\right)}{k_{j}+p_{j}+r}
$$

\footnotetext{
${ }^{14}$ The disutility, of immigrants of being unemployment, is not considered here. Usually migrants are unhappy being unemployed because they risk expulsion, the loss of legal residency permits etc. The introduction of the disutility of immigrant's unemployment status will only enhance the results.

${ }^{15}$ Because of diminishing marginal product of labor.
} 
Then, substituting (9) into (6), we determine that worker $j$ will not shirk if

$$
w \geq w_{o}+\Delta e_{H}+\frac{\Delta e_{H}}{q}\left(k_{j}+p_{j}+r\right) .
$$

While $\Delta e_{H}=e_{H}-e_{L}$.

As we stated above we are concerned with a pooling equilibrium, thus the wages for the natives and for the local workers are identical. Notice that while we are assuming the same wages migrants are identical and the same holds for the local population. Thus all workers in each group act in the same way: either invest high effort or low effort. The condition in (8) specifies two different conditions, one for the local population $(j=N)$ and one for the immigrants $(j=F)$. Thus the probability of losing a job and finding a job depends on the worker's status: local worker or migrant. In equilibrium the probability of finding a job will be $k_{j}$ which may differ for the two types of workers.

\section{The Dynamics of the Model.}

We assume that both the local and the migrants earn the same income $w .{ }^{16}$ In industrialized countries wages are often determined by type of jobs and employers cannot easily discriminate on the remuneration given to workers. On the contrary workers are free to be more productive or less productive. Thus, in principal, there is no wage discrimination between locals and migrants.

As assumed above real wages are thus defined as $w=w_{N} / P$. It is important to note that wages in equilibrium, paid by the employers, are in nominal terms. Moreover, to simplify matters we assume that prices in the host country are constant. The price level, which is used to normalize the wages, differs between the local and foreign workers. Denote by $P_{N}$ the national price index and by $P_{F}$ the prices in the migrant's home country (to simplify we assume that there is only one type of migrant coming from the same original home ${ }^{17}$ country and thus all discount wages with the

\footnotetext{
${ }^{16}$ If wages could differ between the local population and migrants, then the migrants would have a higher wage (a higher cost to be unemployed), however, the local populations' reservation wages would be higher than that of the migrants. Therefore, in equilibrium we would obtain that both groups would have more or less the same wages.

${ }^{17}$ If we would assume more than one country of origin the main results would not change.
} 
same price level). Moreover, we consider migrants who come from a country with a lower price level than the host country.

Immigrants, when entering the host country, have little or no knowledge of the host country and its cost of living. Over time this information is revealed to the immigrant. ${ }^{18}$ Many migrants send a lot of their income to their families as remittances. Therefore, cost of living for the migrants, the price level at which they discount the nominal wages, will be the price level at their home country. However, as the migrant stays longer in the host country, they will start adopting the life-style of the local population and obtain more information regarding the cost of living in the host country. Therefore, the older migrants (those with a longer tenure in the host country) put a higher weight on the local price index when making calculations regarding the real wages. The price level by which the migrant normalizes his wage is a function of 3 parameters: the price level at the home country, the price level in the host country and the weight assigned by the immigrants to each of the prices. The weight is therefore a function of the time the migrant has already spent in the host country and is given by the following function:

$$
P_{f}=\alpha(t) P_{N}+(1-\alpha(t)) P_{F}
$$

where $0 \leq \alpha(t) \leq 1$ and $(1-\alpha(t))$ are respectively the weights assigned to the local price level and to the home country's price level. $t$ denotes the length of time that the migrant has spend it the host country. It is assumed that $\frac{\partial \alpha(t)}{\partial t} \geq 0$ and $t>t, \alpha(t)=1$. Namely, with time the migrant puts a larger weight on the local price level and a smaller one on the price at the home country ${ }^{19}$. Moreover, it is assumed

\footnotetext{
${ }^{18}$ It may also be the case the speed and level of information revealed to the migrant is a function of the size of the network of the foreign local population from the same origin.

${ }^{19}$ The migrants' decision on allowances has the same effect as described above. Migrants, as soon as they arrive in the destination country, remit a lot of their income to their home country, evaluating part of their income with respect to the price of the country of origin. The more they stay in the destination country the less they remit and the more they consume in the destination country. This myopic behavior is however adopted also by foreigners who do not remit. Italian engineers, going to Geneva (SW) in order to work at the CERN, have the same attitude regarding their wages. They evaluate it by Italian prices at the beginning and they work night and day. They do not send money home, but they feel that their wages are very high. The more they stay in destination country, and the more they have a normal life in the host country, the more they consider their wages in purchasing power terms to be not so high, and thus reduce their effort.
} 
that if the migrant spends a sufficient amount of time in the host country, he/she will use the host country's price level only to normalize his wages ${ }^{20}$. We can conclude therefore that even though all migrants (and the local workers) earn the same nominal wages, the newly arrived migrants earn a different real wage than those who have arrived before them ${ }^{21}$.

One should note that the weight applied to the price level, in the country of origin and in the host economy, may be endogenous to the migration strategy and expected consumption patterns. While the assumption made in the model, that the value placed on the country of origin's price level decreases, it may well be that it rather depends on the strategy applied (temporary, permanent, permanent with remittances, etc). One may think that these values are constant within these groups but, in a world with a degree of uncertainty about time spent in the host country, more and more people realize that their intentions are more permanent than temporary. Such a change of weight would not affect the results presented. Moreover, the results presented in (10) are given for each migrant as a function of the time spent in the host country.

\section{Possible Equilibriums}

Let us now return to the equilibrium wage and to the level of effort exerted by the different workers.

As the price level at which the migrants discount their wages is lower than that of the local workers, the real wage received by the local workers is lower than that received by the migrants (and the real wages received by the newly migrants is higher than that of the migrants that arrived earlier). As the migrants stay longer in the host country, their real wages starts converging to the wages of the local population. If the wages in equilibrium are set so that the local worker will exert a high level of effort, $e_{H}$, then it is clear that the migrants will also exert a high level of effort. However, if

\footnotetext{
${ }^{20}$ Since we are analyzing migration of low skilled workers, we assume that the price level in the home country is lower than that of the host country: $P_{N}>P_{F}$. Given (12) it is clear that over time the price level that the migrant uses in the normalization of his wages approaches that of the host country: $P_{f} \rightarrow P_{N}$.

${ }^{21}$ However two migrants with the same time duration, the first with the family at home and the second reunified by the family could make a different effort.
} 
the wages are set in equilibrium so that the local workers exert a low level of effort, $e_{L}$, then it may well be the case that the migrants will exert a high level of effort.

Assume that in the absence of foreign workers the wage is set such that the local workers exert a high level of effort. Denote the number of workers employed in equilibrium as $L_{N}{ }^{0}$. The profits of the capital owners will thus be:

$$
\pi\left(L_{N}^{0}\right)=\tilde{f}\left(\bar{K}, L_{N}^{0} z\right) P_{x}^{0}-C\left(L_{N}^{0} w^{0}\right)
$$

where $\bar{K}$ is the capital level, total output is given by $\tilde{f}(\bar{K}, L z)$, the price of the product by $P_{x}^{0}$ equilibrium wage $w^{0}$ and total cost of production $C\left(L_{N}^{0} w^{0}\right)$.

When migrants enter the country, the equilibrium wage level will change as a result of the changes in the individuals willing to work (and as a result the price level of the products will also change). Thus the wage, which will encourage a high level of effort from the local population, will decrease (see Epstein and Hillman, 2003). Therefore, if the firms continue to pay wages which will stimulate a high level of effort from the local population, then the migrants will also exert a high level of effort.

\subsection{Fixed and equal human capital}

In this section we assume that human capital is equal and fixed for all the workers. So we can concentrate on the worker's productivity as a function their effort.

Now let us consider three different equilibriums with both native workers and migrants: $a$. both the migrants and the native population are exerting a high level of effort, $b$. the native population is exerting a low level while the migrants are exerting a high level and $c$. all workers are exerting a low level of effort:

Case 1a: wages are set at $w^{1}$, both the local and migrants exert a high level of effort,

$$
\pi\left(L_{N}^{1}, L_{F}^{1}\right)=\tilde{f}\left(\bar{K},\left(L_{N}^{1}+L_{F}^{1}\right) e_{H}\right) P_{x}^{0}-C\left(\left(L_{F}^{1}+L_{N}^{1}\right) w^{1}\right)
$$

Case 1b: wages are set at $w^{2}$, the local population exerts a low level of effort, $e_{L}$ and the migrants exert a high level, $e_{H}$, 


$$
\pi\left(L_{N}^{2}, L_{F}^{2}\right)=\tilde{f}\left(\bar{K}, L_{N}^{2} e_{L}+L_{F}^{2} e_{H}\right) P_{x}^{0}-C\left(\left(L_{F}^{2}+L_{N}^{2}\right) w^{2}\right)
$$

Case 1c: wages are set at $w^{3}$, both the local and migrants exert a low level of effort,

$$
\pi\left(L_{N}^{3}, L_{F}^{3}\right)=\tilde{f}\left(\bar{K},\left(L_{N}^{3}+L_{F}^{3}\right) e_{L}\right) P_{x}^{0}-C\left(\left(L_{F}^{3}+L_{N}^{3}\right) w^{3}\right)
$$

where $w^{0}>w^{1}>w^{2}>w^{3}$ and, of course, the number of workers employed in equilibrium in all three cases are not identical. All three equilibriums are possible. We wish to consider the second case where wages have dropped as a result of migration, and in equilibrium, the level of effort of the foreign population is higher than that of the local population. As assumed above, all workers receive the same nominal wages. Therefore, the local population receives, in real terms, a lower wage than the migrants. However, the employer receives a higher level of effort at the same nominal wage level. It is obvious that case b may well be an equilibrium outcome. However, we must note that the profits of the firm and the level of exertion is a function of time.

\subsubsection{A fully inelastic supply of immigrants}

Assume that the number of migrants is fixed in the economy, then over time case $b$ will converge into case $a$ or case $c: \pi\left(L_{N}^{2}, L_{F}^{2}\right) \rightarrow \pi\left(L_{N}^{1}, L_{F}^{1}\right) \quad$ or $\pi\left(L_{N}^{2}, L_{F}^{2}\right) \rightarrow$ $\pi\left(L_{N}^{3}, L_{F}^{3}\right)$. Namely, it is not clear whether the migrants are increasing the average level of effort exerted or decreasing it. The reason for this is that over time the migrants' real wages converge on that of the native population. As the real wages converge, the level of efforts extracted by the workers also converge as well as their productivity. At the same time the labor force has increased, the wages have dropped and thus the wages may drop to a level such that both groups exert a high or low level of effort.

We conclude therefore that, 
Migrants may well exert a higher level of effort than the local population. However, with time, the level of effort exerted by the migrants and the local population will converge.

Notice that the effort exerted by the worker is a function of the unemployment level. If we consider, in addition, that migrants do not know, on their arrival, the level of employment and unemployment, and that over time this knowledge is revealed to them, then this new knowledge will affect their effort invested at the work place. ${ }^{22}$ Their efforts will converge over time and become equal to that of a local worker. Thus, if we incorporate, directly into the model above, this lack of information about the unemployment level, it would only enhance the results presented above.

\subsubsection{Constant inflow of immigrants.}

As a direct result, the longer the migrants are in the host country the more they appear like the local population. Therefore, over time, the employers will employ the newcomers instead of the old migrants and the local population. The rate at which the hiring and firing occurs will depend on the costs and on the rate at which the effort of the migrants change over time ${ }^{23}$.

\subsection{Heterogenous human capital}

Let us consider the case where human capital is an important component of total workers productivity. Assume that immigrants and the local population have only two types of human capital High, $h_{H}$, and Low, $h_{L}$. The total productivity can thus be written as follows: $z(h, e)$ and the production function can be written as follows: $\tilde{f}(\bar{K}, L z(h, e))$. We assume therefore that human capital and effort exerted at the

\footnotetext{
${ }^{22}$ The information level can also be a function of the size of the existing network at the time of arrival of the migrants into the host country. The reason for this is that as the size of the network increases the new migrant may receive more information and adapt more easily to the local population.

${ }^{23}$ Low exertion of effort, if not accompanied by a return home, will increase the unemployment rate among immigrants staying a long period of time in the host country. Looking at the data on first and second generation migrants there is evidence of this correlation. In France in 1993 the unemployment rate among natives was $10 \%$ while among foreigners it was $20.6 \%$; moreover, the unemployment rate among the natives aged under 25 years old was $25.2 \%$ while among foreigners of the same age it was $32.3 \%$. In the Netherlands in the same period of time, the unemployment rate was $5.7 \%$ among natives and $19.6 \%$ among foreigners, and respectively $9.8 \%$ and $25 \%$ among young natives and foreigners. In
} 
workplace can be substitutes. Namely if a worker with low human capital increases his effort at the workplace he will be identical to a worker with high human capital with low exerted effort. Let us consider the following cases:

a. Natives and foreigners have the same level of productivity, $z(h, e)$. As described above, the migrants' real wages decrease over time and as a result the workers may exert less effort at the workplace. If the migrants exert less effort then this will not be compensated by an increase in human capital as the employers will fire the foreigners and employ recently arrived migrants or the local population.

b. If the human capital of the foreigners and natives are equal to each other and at a low level, and at the same time, the effort invested by the foreigners is higher than that of the local population: $e n_{L}<e f_{H}$, then foreigners productivity level will be higher than that of the local population: $z_{f}(h, e)>z_{n}(h, e)$. In this case the employer will prefer to hire foreigners in the first period. If in the second period the effort of the foreigners declines without any increase in human capital, then the employer will be indifferent as to employing natives or second period foreigners, but he will prefer first period immigrants. If on the other hand, the human capital of the foreigners increase over time, while the effort of others is reduced such that it compensates for the reduction in exerted effort, then the employers will also prefer foreigners in the second period.

\section{The Local workers and the employers}

As defined above the utility of the workers is given by

$$
\begin{aligned}
& U(C)=C \\
& \text { s.t. } \\
& \qquad \begin{array}{l}
P(T-e) \leq w_{N} \\
C
\end{array} \quad P(T-e)
\end{aligned}
$$

Germany the unemployment rate was $4.9 \%$ and $12.7 \%$ for all natives and foreigners, whilst for the population aged under 25 it was $4.8 \%$ and $14.1 \%$ respectively (see, Böhning 1995). 
Total consumption of the workers is a function of the level of effort exerted by the workers. $e$,

Denote the aggregate demand as $D\left(e_{f}, e_{n}, P\right)$, namely the demand for the products is a function of the effort exerted by the different groups and the price of the products. Moreover, as the levels of exerted effort increase the demand for the products decreases. Let us denote the supply by $S\left(z_{n}, z_{f}, P\right)$, namely the supply is a function of the productivity levels of the different groups and the price level (which in equilibrium is a function of the wage level). It is clear that as the level of productivity increases the supply increases.

We now consider the effect, which changes in the effort exerted by the different groups, has on the equilibrium, quantity and prices. In equilibrium, the quantity demanded equals the quantity supplied. Let us consider the following situation under which both the local and the migrant workers exert the same effort: $e_{n}=e_{l}=e$ and $z_{n}=z_{l}=z$. In this case $D(e, e, P)=S(z, z, P)$ and we obtain that the quantities and prices in equilibrium equal:

$$
q_{b}^{l}+q_{b}^{n}=q_{b}^{*} ; \quad p_{b}^{*}
$$

where $q_{b}^{j}$ and $p_{b}{ }^{j}$ are the quantities and the prices group $j=n, l$ in equilibrium.

$q_{b}^{*}$ and $p_{b}^{*}$ denote the total quantity and price at equilibrium.

Case 1: Both the local population and the migrants have the same level of productivity while the migrants invest more effort than the local population: $e_{n}<e_{f}^{1}$ and $z_{n}=z_{l}=z$. As a result of migration denote the new quantities and prices as $q_{1}^{j}$ and $p_{1}^{j}$ In this case we would obtain that

$$
\begin{gathered}
q_{1}{ }^{f}<q_{b}{ }^{f} ; q_{1}{ }^{n}>q_{b}{ }^{n} q_{1}^{*}<q_{b}^{*} \\
\text { and } \\
p_{1}<p_{b}^{*}
\end{gathered}
$$


As the immigrants spend more effort at the workplace we can see from (16) that the immigrants will have a lower consumption level. This will decrease the total demand for products, which will, in turn, decrease the price of the products. As the price level decreases, the demand of the local population will increase.

Case 2: Now let us take this one step further. Let us assume that the above analysis is true for second year immigrants. Here the employers decide to replace the second year immigrants with those newly arrived. In this case we will obtain: $e_{n}<e_{f}^{1}<e_{f}^{2}$ and $z_{n}<z_{2}$. The supply will increase as the employers have more efficient workers. As the newly arrived immigrants exert more effort at the workplace, the demand for the them will decrease relative to that of the second year immigrants. At the same time the demand for the local population will increase as the price level has increased and therefore the real wage increased.

The local workers benefits: The local workers are better off, their real wages have increased as has their consumption. It is true that maybe some of them are worse off as they have been replaced by newly arrived migrants, however, this is not clear as the decrease in prices has increased the quantity demanded. The unemployed are also better off as their real unemployment benefits have increased.

The capital owners' benefit: Each firm sees as given the wages and the price level and it is assumed that each firm is small and has no market power. Thus, the capital owners benefit from replacing an "older" migrant with a "newly" arrived one.

The reason for this result is that the employer will receive a better worker, who extracts more effort in the workplace and earns the same wage as the "older" migrant. At the firm level the price of the product is given and thus his profits increase. However, in equilibrium it is not clear if the firms' profit increases or decreases, as real wages increase and production increases. It is clear that for each firm it is optimal to replace its "older" migrant with the newly arrived migrant. 


\section{Concluding Remarks and Policy implications:}

In this paper we have provided a rationale for the newly-arrived legal migrants to exert more effort than the local population. ${ }^{24}$ Moreover, new migrants exert more effort that the "older" ones and invest a higher level of effort, but over time, the level of effort exerted by the local population and the migrants converge.

Fundamentally, if immigrants have the same human capital as the natives, firms prefer new immigrants to "older" immigrants, and if they are able to fire "older" immigrants and employ new ones they will do so. This implies that employers will always prefer newly-arrived migrants. ${ }^{25}$ On the other hand, as shown above, the local population may also benefits from newly-arrived migrants. However, both the local population and the employers gain disutility from migrants who stay too long in the host country. The policy that will achieve this situation will be to limit the time the migrants can stay in the host country and replace migrants with newly arriving migrants. This policy is a temporary migration policy.

Such a temporary migration policy will benefit both the employers and the workers. Under this policy, migrants will enter the host country for a given period of time. At the end of the period the migrants will return to their home country. If the host country still needs migrant workers, the old workers will be replaced by the newly arrived migrants exerting a high level of effort.

The rational for a temporary migration policy derives not from the welfare costs, nor from social or labor market competition, but from the profit maximization choice of the employer and the benefit to the final consumer. The same rationale applies to the more recent circular migration policy in which the repetition of temporary migration spells with the consumption focused in the origin country could reproduce the effort and the productivity behavior described above.

The question is how such a policy can be implemented? The way to implement such a policy is to create a contracted temporary migrant policy, which limits the period of time that the migrants can stay in the host country. When migrants leave the

\footnotetext{
${ }^{24}$ Our model considers only legal immigration. With regard to illegal immigration, see for example Djajić (1997). For a perspective on efficiency wages with illegal immigration in a dual labor market model, see Carter (1999).

${ }^{25}$ If the migrant invests in the specific human capital of the country of destination, his productivity increases and thus counteracts the decline of his productivity imputed to the reduction of effort. The final result is not clear: the two forces can be of different strength. However many jobs filled by migrants do not need any human capital investment and there is no increase in productivity.
} 
host country, new migrants will enter, and these will exert a high level of effort in the workplace.

Theoretically, one new migrant should enter every day and one should leave. However, training migrants and teaching them the new jobs entail costs. Moreover, also to be considered are the transportation costs, which may well fall on the capital owners. Thus, the policy should also take account of the costs of changing migrants and calculate the optimal time that a migrant should stay in the host county. Temporary contracted migration has many problems; the main one is ensuring that legal migrants will leave the host country on the conclusion of their contracts. There are many ways to ensure that they do so (see Epstein, Hillman and Weiss (1999) and chapter 7 in Boeri, Gordon and McCormick (2002)). Temporary migration may well benefit the sending country because the temporary migrants are likely to increase their human capital in the host country and thus return to the home country with greater human capital. ${ }^{26}$

Note that the capital owners will benefit from migration. Their level of benefit will be a function of the length of the contract. On the other hand, however, the native labor force, which will be unemployed as a result of such a policy, will be harmed. Yet the native population, or better the native consumers (which include the unemployed) will prefer to have a large turnover of migrants with a higher effort and lower consumption.

The favorable sentiment of capital owners and the local population towards migrants may arise when temporary migration policies are adopted. If such policies are adopted, the level of effort extracted from migrants is optimized, prices decrease, real wages increase, and welfare grows.

\footnotetext{
${ }^{26}$ See also the economic case for broad benefits from immigration based on the human-capital upgrading of domestic unskilled labor made by Schmidt, Stilz, and Zimmermann (1994) and the positive effect of reducing child labor in the host country see Epstein and Kahana (2008)..
} 


\section{References}

Arad, R.W. and Hillman, A.L. (1979) The collective good motive for immigration policy. Australian Economic Papers 18: 243-257.

Barrett A., McCarthy Y. (2008) Immigration and Welfare Programmes: Exploring the Interactions between Immigrant Characteristics, Immigrant Welfare Dependence and Welfare Policy, Oxford Review Economic Policy, 24(3), 542-559.

Bauer T., Sinning M.,(2005) The saving behaviour of Temporary and Permanent Migrants in Germany, IZA D.P. 1632

Benhabib, J. (1996) On the political economy of immigration. European Economic Review 40: 1737-1743.

Boeri, T., Hanson G. and McCormick, B. (2002) Immigration Policy and the Welfare System, Oxford University Press.

Böhning R.W., (1995) Labour Market Integration in Western and Northern Europe. Which way are we heading?, in Böhning R.W., Zegers de Beijl R., 1995, The Integration of Migrant Workers in the Labour Market: Policies and their Impact, I.L.O. Employment Department, International Migration Papers, n. 8

Bonin, H., Raffelhüschen B., and Walliser, J. (2000) Can immigrants alleviate the demographic burden? An assessment with generational accounting. Finanzarchiv, 57: $1-21$

Borjas G. (1994) The Economics of Immigration, Journal of Economic Literature, 32: $1667-717$.

Borjas G., (1999) Immigration and the Welfare Magnets, Journal of Labour Economics, vol,.17, n.4, part1:607-637

Borjas G. (2003) The Labour Demand Curve is Downward Sloping: Reexamining the Impact of Immigration in the Labour Market, Quarterly Journal of Economics, 118: 1335-74.

Buchanan, J. M., (1975) The Samaritan's dilemma. In Edmund Phelps, ed., Altruism, Morality and Economic Theory, Russell Sage, New York: 71-85.

Carling J. 2008, The Determinants of Migrant Remittances, Oxford Review of Economic Policy, vol.24-3, pp.582-599.

Card D., (2005) Is the New Immigration Really So Bad? Economic Journal, 115, F300-F323.

Carter, T. J. (1999) Illegal immigration in an efficiency wage model. Journal of International Economics 49: 385-401.

Castronova E., Kayser H., Frick J., Wagner G. (2001) Immigrants, Natives and Social assistance: Comparative Take-up under Comparable Circumstances, International Migration Review, vol.35,(3):726-748.

Cortes KE, 2004, Are Refugees Different from Economic Immigrants? Some Empirical Evidence on the Heterogeneity of immigrant Groups in the United States, Review of Economics and Statistics, 86(2) 465-480 .

De Giorgi G., Pellizzari M. (2006) Welfare Migration in Europe and the Cost of a Harmonised Social Assistance, IZA D.P.2094

Djajić, S. (1997) Illegal immigrants and resource allocation. International Economic Review 38: 97-117.

Dustamann C. and Fabbri F. (2005) Immigrants in the British Labour Market, Fiscal Studies, 26 (4): 423-470.

Dustmann C. and Weiss Y. (2007) Return Migration: Theory and Empirical Evidence, CREAM Discussion paper series n.2/07. 
Epstein, G. S., Hillman, A. L. (2003) Unemployed Immigrants and Voter Sentiment in the Welfare State, Journal of Public Economics: 1641-1655.

Epstein, G.S., Hillman A.L. and Weiss A. (1999) Creating Illegal Immigrants, Journal of Population Economics, 12(1): 3-21.

Epstein, G.S. and Kahana, N. (2008) Child Labor and Temporary Emigration Economics Letters 99(3), 545-548.

Epstein G.S., Nitzan S. (2006) The Struggle over Migration Policy, Journal of Population Economics, 19(4): 703-723.

European Commission, (2007) On Circular Migration and Mobility Partnership between the European Union and Third Countries, $\operatorname{COM(2007),~final~Bruxelles,~} 16$ May.

Filer R. (1992) The Effect of Immigrant Arrival on Migratory Patterns of Native Workers, in Borjas G.J., Freeman R. (eds) Immigration and the Work Force, University of Chicago Press, Chicago.

Fuest, C. and Thum, M. (2001) Immigration and skill formation in unionized labour markets. European Journal of Political Economy, 18.

Funhouser E:, (1995), Remittances from International Migration, The Review of Economic and Statistsics, vol.77.1, pp.137-146.

Galor O., Stark O., (1990), Migrants' Savings, the Probability of Return Migration and Migrants' Perfomance, International Economic Review, vol.31-2, pp.463-467.

Galor O., Stark O., (1991), The probability of return migration, migrants' work effort, and migrants' performance. Journal of Development Economics 35(2): 399 - 405.

Gans, H. (1979) Symbolic Ethnicity: The Future of Ethnic Groups and Cultures in America, Ethnic and Racial Studies, 2(1): 1-20.

Gans, H. (1996) Second-Generation Decline. Scenarios for the Economic and Ethnic Futures of the post-1965 American immigrants, in Immigration and Integration in Post-Industrial Societies. Theorical analysis and policy-related research, ed Carmon N. 65-85. Basingstoke:Macmillan,

Glazer, N., Moynihan D. (1970) Beyond The Melting Pot, Mass. MIT Press, , Cambridge.

Kahanec M., Shields M., 2010, The Working Hours of Immigrants in Germany: Temporary versus permanent, IZA DP 4735.

Holst E:, Schäfer A., Schrooten M., 2010, Gender, Transnational Networks and Remittances: Evidence from Germany, SOEP paper 296.

Kirdar G.M., 2008, Labor Market Outcomes, Savings Accumulation, and Return Migration, Labour Economics, 16(4) 418-428.

Kirdar G.M., 2009, Source Country Characteristics and Immigrants' Migrant Duration and Saving Decisions, MPRA paper. N 13322.

Kumku E.M., 1989, The Saving Behaviour of Migrant Workers: Turkish Workers in W. Germany, Journal of Development Economics, 30, 273-286.

Hansen J., Lofstrom M. (2003) Immigrants assimilation and Welfare Participation: Do Immigrants Assimilate into or out of Welfare? Journal of Human Resources, 38, n.1: 74-98.

Hillman, A. L. and Weiss, A. (1999) A theory of permissible illegal immigration. European Journal of Political Economy 15: 585-604.

Hillman, A. L. (2002) Immigration and intergenerational transfers, in H. Siebert, ed., Economic Policy For Aging Societies, Springer, Berlin.

Lee, R. D. and Miller, T. W. (1998) The current fiscal impact of immigration and their descendants: beyond the immigrant household. In J.P. Smith and B. 
Edmonston, The Immigration Debate, National Academy Press: Washington, DC: 183-205.

Lonzano F.A., 2010, Understanding the workweek of foreigner born workers in the United States, Review Economic Household, 8, 83-104.

Mansoor A., Quillin B., 2006, Migration and Remittances, Eastern Europe and the Former Soviet Union, The World Bank.

Mazza, I. and van Winden, F.W. (1996) A political economy analysis of labor migration and income distribution. Public Choice 88: 333-363.

Newland K., Dovelyn A. (2007) How can circular migration and sustainable return serve as development tools? , background paper for the first meeting of the Global Forum on Migration and Development (GFMD), Bruxelles, 9-11 July 2007.

Ottaviano G.M., Peri G. (2006) Rethinking the effects of immigration on wages, NBER Working Paper No. W12497.

Pellizzari M., 2011, The use of Welfare of migrants in Italy, mimeo.

Picha M. Zhu Y., 2007, Precautionary saving by Natives and Immigrants in Germany, IZA DP.2942.

Poirine B., (1997) A Theory of Remittances as an Implicit Family Loan Arrangement, World Development, vol.25-4, pp.589-611.

Portes A., Zou M. (1993) The New Second Generation: Segmented Assimilation and its Variants Among Post-1965 Immigrant Youth, The Annals of the American Academy of Political and Social Sciences 530:74-96.

Riphan R. (2004), Immigration Participation in Social Assistance Programs, Applied Economics Quarterly, 50 (4): 329-362.

Reyneri E., 2011,Preliminari results on the hours worked by migrants, mimeo.

Schaeffer P.V., 1995, The Work effort and the Consumption of Immigrants as a Function of Their Assimilation, International Economic Review, vol.36, n.3, pp.625-642.

Schmidt, Christophe M., Stilz, Anette, and Zimmermann, Klaus F. (1994) Mass migration, unions, and government intervention. Journal of Public Economics, 55: $185-201$.

Sinn, Hans-Werner (995) A theory of the welfare state. Scandinavian Journal of Economics 97: 495-526.

Shapiro, C. and Stiglitz, J. (1984) Equilibrium unemployment as a worker discipline device. American Economic Review 74: 433-44.

Speciale B., Barigozzi M., 2009, Immigrant's legal Status, Permanence in the Destination Country and the Distribution of Consumption Expenditure, ECARES WP 2009-019.

Storesletten, K. (2000) Sustaining fiscal policy though immigration. Journal of Political Economy, 108: 300-323.

Venturini A. (1997) L'offerta differenziale dello straniero, Economia Politica, n.2, annoXIV: $257-282$.

Venturini A. (2004), Post War Migration in Southern Europe, An Economic Approach, CUP, Cambridge Mass.

Venturini A. (2008) Circular Migration as an employment strategy for Mediterranean countries, CARIM/RSCAS ASN n.39

Venturini A., Villosio C. (2008), Assimilation of migrants in recent immigration countries: The Italian Experience, OXREP, vol.23, 4, 518-542.

Wong, Kar-yiu, 1995. International Trade in Goods and Factor Mobility. MIT Press, Cambridge. 